\title{
DIVERSITY OF NUTRITION AMONG MALE AND FEMALE UKRAINIAN STUDENTS
}

\author{
Józef Bergier, ${ }^{1, A, B, C, D, E}$ Barbara Bergier, ${ }^{1, A, B, C, D, E}$ Anatolii Tsos $2, A, B, C, D, E$ \\ ${ }^{1}$ Pope John Paul II State School of Higher Education, Biała Podlaska, Poland \\ ${ }^{2}$ Lesya Ukrainka Eastern European National University in Lutsk, Ukraine

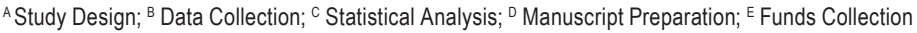 \\ Address for corpespondence: \\ Józef Bergier \\ Pope John Paul II State School of Higher Education \\ Sidorska 95/97, 21-500 Biała Podlaska, Poland \\ E-mail: rektor@pswbp.pl
}

\begin{abstract}
Ahstract Adequate nutrition is one of the most important factors of a good state of health. The objective of the study was recognition of the mode of nutrition and behaviours related with concern about silhouette among students from the Ukraine.

Materials and Method. The study was conducted in 2013 among 2,125 students, including 1,291 females and 834 males, from 12 study specialties at the National University in Lutsk. The method of a diagnostic survey was applied with the use of a questionnaire. The study showed significant differences in the regularity of consumption of meals to the benefit of males. Females, in their behaviours, more frequently avoided eating, felt fear of gaining weight, and lost control over eating. With respect to behaviours related with concern about silhouette, females significantly more often applied exercises in order to reduce body weight, while males in order to gain body weight. A positive behaviour in both sexes was a trace application of drugs and other pharmacological means to improve own silhouette.
\end{abstract}

Key Worlds nutrition, female students, male students, Ukraine

\section{Introduction}

Nutritional habits and their regularity exert a great effect on our health. An important issue is the current investigation of nutritional behaviours of students from various countries due to their cultural specificity (Antal et al., 2006; Brunt, Rhee, 2008; Delinsky, Willson, 2008; Kiziltan, Karabudak, Unver, Sezgin, Unal, 2006; Mammas, Bertsias, Linardakis, Moschandreas, Kafatos, 2006; Popowa-Ramova, 2015). Polish studies conducted in 2000 showed that the majority of the population (68\%) consider that they eat healthily; however, as many as $21 \%$ had an opposite opinion concerning this problem (Falkowska, 2000).

In Poland, studies concerning nutrition among female students are relatively common and pertain to very different types of universities, mainly medical (Karina, Rektor, 2005; Krzych, 2004; Olędzka, Węgłowska, Szczepańska-Chudy, Bobrowska, 2004; Paśko, Krośniak, Chłopicka, Zachwieja, 2005; Smorczewska-Czupryńska, Ustymowicz-Farbiszewska, Cymek, Dubiel, Karczewski, 2009; Stefańska, Ostrowska, Czapska, Karczewski, 2005; Szponar, Krzyszycha, 2009; Zarzecka-Baran, Wojdak-Haasa, 2008), physical education (Gacek, 2004; Medrela-Kuder, 
2003) pedagogical (Mięsowicz, Palus, 2002), agricultural (Wyka, Żechałko-Czajkowska, 2007), and universities of technology (Malara, Góra-Kupilas, Jośko, 2006; Olędzka, Moczydłowska, Rogalska-Niedźwiedź, 2002).

The researchers also undertook studies concerning the specificity of nutrition of female students (Jasnos et al., 2003; Rasińska, 2009; Smorczewska-Czupryńska, Ustymowicz-Farbiszewska, Cymek, Dubiel, Karczewski, 2009; Socha, Borawska, Markiewicz, Charkiewicz, 2009; Wojciechów-Gazel, Mickiewicz, Krzyśków, 2013).

The following of nutritional habits and health behaviours related with concern about silhouette among students, with consideration of specificity of males and students, allows even more comprehensive recognition of their preferences and factors which condition these preferences. The importance of the problem encouraged the authors to recognize the mode of nutrition of female and male students in Ukraine.

\section{Methodology of research}

The objective of the study was recognition of the mode of nutrition of students from Ukraine, with consideration of the specificity of sex.

\section{Material and methods}

The study was conducted in 2013 among 2,125 students, including 1,291 females and 834 males, aged 17-22 from 12 study specialties: philology, international relations, national sciences, physical culture and health, pedagogy, law, biology, geography, history, physics, fine arts, and mathematics, at the National University in Lutsk, Ukraine. The method of a diagnostic survey was applied, using a questionnaire designed at the Institute of Rural Health in Lublin, Poland, which contained questions concerning nutritional behaviours, behaviours concerning silhouette, and including the application of exercises in order to gain or reduce body weight.

\section{Results}

While analysing differences in nutrition among male and female students the following was considered: number of meals consumed per day, place of their consumption, behaviours related with nutrition, and behaviours related with concern about the appearance of the silhouette. Statistical analysis was performed using the software STATISTICA V10; significance level was set at $p=0.05$.

\section{Number of meals consumed during the day}

Students from Ukraine most frequently consumed 3 meals per day (47\%), and in a similar proportion - 4 and more meals (28\%), and 1-2 meals (24.5\%) (Table 1).

Males consumed meals significantly more often than females. In the case of 4 and more meals, their indicators were $36.6 \%$ and $23.2 \%$, respectively. In turn, females more often consumed $1-2$ meals, $29.9 \%$ and $16.2 \%$, respectively. Possibly, the observed differences resulted from the fact that females try to eat more rarely in concern about their silhouette, which is not favourable for health.

It is also noteworthy that males significantly more frequently consumed main meals every day. This concerned the first and second breakfast, afternoon snack and supper. No significant differences between males and females were found according to the consumption of dinner. Females, to a higher extent, did not consume main meals: first breakfast $-34.5 \%$, compared to $27.7 \%$ of males, second breakfast $-12.4 \%$, compared to $6.5 \%$ of males, afternoon 
snack - $17.8 \%$, compared to $12.8 \%$ of males, and supper $-7.8 \%$, compared to $2.0 \%$ of males. The positive phenomenon was the fact that only approximately $1 \%$ of both males and females did not eat dinner. The problem of consumption preferences of individual product groups has not been undertaken in this study.

Table 1. Number of frequency of consumption of meals by students from Ukraine, according to sex*

\begin{tabular}{|c|c|c|c|c|}
\hline \multicolumn{5}{|c|}{ Number of meals consumed per day } \\
\hline Sex & $1-2$ & 3 & 4 or more & Statistics \\
\hline Females & $351(29.9 \%)$ & $550(46.9 \%)$ & $272(23.2 \%)$ & \multirow{3}{*}{$\begin{array}{l}X^{2}=64.78 \\
p<0.0001\end{array}$} \\
\hline Males & $124(16.2 \%)$ & $362(47.3 \%)$ & $280(36.6 \%$ & \\
\hline Total & $475(24.5 \%)$ & $912(47.0 \%)$ & $552(28.5 \%)$ & \\
\hline \multicolumn{5}{|c|}{ Frequency of consumption of first breakfast } \\
\hline Sex & Every day & $\begin{array}{c}\text { Several times } \\
\text { a week }\end{array}$ & I do not eat & Statistics \\
\hline Females & $427(39.8 \%)$ & $276(25.7 \%)$ & $370(34.5 \%)$ & \multirow{3}{*}{$\begin{array}{c}X^{2}=13.14 \\
p=0.0014^{*}\end{array}$} \\
\hline Males & $270(39.7 \%)$ & $222(32.7 \%)$ & $188(27.7 \%)$ & \\
\hline Total & $697(39.8 \%)$ & $498(28.4 \%)$ & $558(31.8 \%)$ & \\
\hline \multicolumn{5}{|c|}{ Frequency of consumption of second breakfast } \\
\hline Sex & Every day & $\begin{array}{c}\text { Several times } \\
\text { a week }\end{array}$ & I do not eat & Statistics \\
\hline Females & $439(39.8 \%)$ & $528(47.8 \%)$ & $137(12.4 \%)$ & \multirow{3}{*}{$\begin{array}{l}X^{2}=31.43 \\
p<0.0001^{*}\end{array}$} \\
\hline Males & $378(51.2 \%)$ & $312(42.3 \%)$ & $48(6.5 \%)$ & \\
\hline Total & $817(44.4 \%)$ & $840(45.6 \%)$ & $185(10.0 \%)$ & \\
\hline \multicolumn{5}{|c|}{ Frequency of consumption of dinner } \\
\hline Sex & Every day & $\begin{array}{c}\text { Several times } \\
\text { a week }\end{array}$ & I do not eat & Statistics \\
\hline Females & $997(79.4 \%$ & $241(19.2 \%)$ & $17(1.4 \%)$ & \multirow{3}{*}{$\begin{array}{c}X^{2}=2.40 \\
p=0.3008\end{array}$} \\
\hline Males & $630(78.4 \%)$ & $168(20.9 \%)$ & $6(0.8 \%)$ & \\
\hline Total & $1,627(79.0 \%)$ & $409(19.9 \%)$ & $23(1.1 \%)$ & \\
\hline \multicolumn{5}{|c|}{ Frequency of consumption of afternoon snack } \\
\hline Sex & Every day & $\begin{array}{c}\text { Several times } \\
\text { a week }\end{array}$ & I do not eat & Statistics \\
\hline Females & $377(34.4 \%)$ & $523(47.8 \%)$ & $195(17.8 \%)$ & \multirow{3}{*}{$\begin{array}{l}X^{2}=15.42 \\
p=0.0005^{*}\end{array}$} \\
\hline Males & $294(42.7 \%)$ & $306(44.5 \%)$ & $88(12.8 \%)$ & \\
\hline Total & $671(37.6 \%)$ & $829(46.5 \%)$ & $283(15.9 \%)$ & \\
\hline \multicolumn{5}{|c|}{ Frequency of consumption of supper } \\
\hline Sex & Every day & $\begin{array}{c}\text { Several times } \\
\text { a week }\end{array}$ & I do not eat & Statistics \\
\hline Females & $780(64.6 \%)$ & $333(27.6 \%)$ & $94(7.8 \%)$ & \multirow{3}{*}{$\begin{array}{l}X^{2}=133.24 \\
p<0.0001^{*}\end{array}$} \\
\hline Males & $714(87.5 \%)$ & $86(10.5 \%)$ & $16(2.0 \%)$ & \\
\hline Total & $1,494(73.9 \%)$ & $419(20.7 \%)$ & $110(4 \%)$ & \\
\hline
\end{tabular}

*The number of answers is smaller than the total number of respondents, because they did not always reply to all of the questions. Statistical significance at $p<0.05$.

\section{Place of consumption of meals}

The analysis covered 5 main meals, with the indication of their consumption at home or outside home. The students ate breakfasts and suppers nearly exclusively at home, $96.0 \%$ and $93.8 \%$, respectively (Table 2). 
Approximately $70 \%$ of students consumed the remaining meals at home. Females significantly more often than males had breakfast at home, while males - the second breakfast $-77.1 \%$ and $65.9 \%$, respectively. Considering the place of consumption of the remaining meals, i.e. dinner, afternoon snack and supper, no significant differences were observed.

Table 2. Place of consumption of meals by students from Ukraine, according to sex*

\begin{tabular}{|c|c|c|c|}
\hline \multicolumn{4}{|c|}{ Where do you eat first breakfast? } \\
\hline Sex & At home & Outside home & Statistics \\
\hline Females & $716(97.0 \%)$ & $22(3.0 \%)$ & \multirow{3}{*}{$\begin{array}{c}X^{2}=4.43 \\
p=0.0352\end{array}$} \\
\hline Males & $498(94.7 \%)$ & $28(5.3 \%)$ & \\
\hline Total & $1,214(96.0 \%)$ & $50(4.0 \%)$ & \\
\hline \multicolumn{4}{|c|}{ Where do you eat second breakfast? } \\
\hline Sex & At home & Outside home & Statistics \\
\hline Females & $679(65.9 \%)$ & $351(34.1 \%)$ & \multirow{3}{*}{$\begin{array}{l}X^{2}=25.77 \\
p<0.0001^{*}\end{array}$} \\
\hline Males & $560(77.1 \%)$ & $166(22.9 \%)$ & \\
\hline Total & $1,239(70.6 \%)$ & $517(29.4 \%)$ & \\
\hline \multicolumn{4}{|c|}{ Where do you eat dinner? } \\
\hline Sex & At home & Outside home & Statistics \\
\hline Females & $884(70.7 \%)$ & $366(29.3 \%)$ & \multirow{3}{*}{$\begin{array}{c}X^{2}=0.77 \\
p=0.3811\end{array}$} \\
\hline Males & $554(68.9 \%)$ & $250(31.1 \%)$ & \\
\hline Total & $1,438(70.0 \%)$ & $616(30.0 \%)$ & \\
\hline \multicolumn{4}{|c|}{ Where do you eat afternoon snack? } \\
\hline Sex & At home & Outside home & Statistics \\
\hline Females & $704(74.7 \%)$ & $238(25.3 \%)$ & \multirow{3}{*}{$\begin{array}{c}X^{2}=0.17 \\
p=0.6825\end{array}$} \\
\hline Males & $468(73.8 \%)$ & $166(26.2 \%)$ & \\
\hline Total & $1,172(74.4 \%)$ & $404(25.6 \%)$ & \\
\hline \multicolumn{4}{|c|}{ Where do you eat supper? } \\
\hline Sex & At home & Outside home & Statistics \\
\hline Females & $1,043(93.5 \%)$ & $73(6.5 \%)$ & \multirow{3}{*}{$\begin{array}{c}X^{2}=0.52 \\
p=0.4707\end{array}$} \\
\hline Males & $756(94.3 \%)$ & $46(5.7 \%)$ & \\
\hline Total & $1,799(93.8 \%)$ & $119(6.2 \%)$ & \\
\hline
\end{tabular}

* The number of answers is smaller than the total number of respondents, because they did not always reply to all of the questions. Statistical significance at $p<0.05$.

\section{Behaviours related with nutrition}

The analysis included five behaviours, which in as many as four cases significantly differentiated the attitudes of males and females. Females more often reported: avoidance of eating meals, and loss of control over eating $29.8 \%$, compared to $23.3 \%$ of their male colleagues (Table 3 ).

No significant differences were found only with respect to the irregularity of nutrition, which concerned $28.7 \%$ of females and $26.4 \%$ of males.

Also, females significantly more frequently than males provoked vomiting, $10.8 \%$ and $6.5 \%$, respectively; however, these behaviours were relatively rare.

The results obtained indicate that the mode of nutrition in females is far from being the correct behaviour. 
Tahle 3. Behaviours related with nutrition among Ukrainian students, according to sex

\begin{tabular}{|c|c|c|c|}
\hline \multicolumn{4}{|c|}{ Loss of control over eating } \\
\hline Sex & No & Yes & Statistics \\
\hline Females & $906(70.2 \%)$ & $385(29.8 \%)$ & \multirow{3}{*}{$\begin{array}{l}X^{2}=11.00 \\
p=0.0009\end{array}$} \\
\hline Males & $640(76.7 \%)$ & $194(23.3 \%)$ & \\
\hline Total & $1,546(72.8 \%)$ & $579(27.2 \%)$ & \\
\hline \multicolumn{4}{|c|}{ Fear of gaining weight } \\
\hline Sex & No & Yes & Statistics \\
\hline Females & $1,004(77.8 \%)$ & $287(22.2 \%)$ & \multirow{3}{*}{$\begin{array}{l}X^{2}=142.94 \\
p<0.0001^{*}\end{array}$} \\
\hline Males & $806(96.6 \%)$ & $28(3.4 \%)$ & \\
\hline Total & $1,810(85.2 \%)$ & $315(14.8 \%)$ & \\
\hline \multicolumn{4}{|c|}{ Provoking vomiting } \\
\hline Sex & No & Yes & Statistics \\
\hline Females & $1,152(89.2 \%)$ & $139(70.8 \%)$ & \multirow{3}{*}{$\begin{array}{l}X^{2}=11.30 \\
p=0.0008^{*}\end{array}$} \\
\hline Males & $780(93.5 \%)$ & $54(6.5 \%)$ & \\
\hline Total & $1,932(90.9 \%)$ & $193(9.1 \%)$ & \\
\hline \multicolumn{4}{|c|}{ Avoiding eating } \\
\hline Sex & No & Yes & Statistics \\
\hline Females & $833(64.5 \%)$ & $458(35.5 \%)$ & \multirow{3}{*}{$\begin{array}{l}X^{2}=108.20 \\
p<0.0001^{*}\end{array}$} \\
\hline Males & $710(85.1 \%)$ & $124(14.9 \%)$ & \\
\hline Total & $1,543(72.6 \%)$ & $582(27.4 \%)$ & \\
\hline \multicolumn{4}{|c|}{ Irregular nutrition } \\
\hline Sex & No & Yes & Statistics \\
\hline Females & $921(71.3 \%)$ & $370(28.7 \%)$ & \multirow{3}{*}{$\begin{array}{c}X^{2}=1.31 \\
p=0.2516\end{array}$} \\
\hline Males & $614(73.6 \%)$ & $220(26.4 \%)$ & \\
\hline Total & $1,535(72.2 \%)$ & $590(27.8 \%)$ & \\
\hline
\end{tabular}

Statistical significance at $p<0.05$.

\section{Behaviours related with concern about own silhouette}

It is commonly considered that especially women during the period of their youth, and certainly during the period of university studies, are particularly concerned about the appearance of their silhouette. Thus, there arises the question whether the behaviours of female students are accompanied by their attitudes promoting health. Unfortunately, this image is only half-way positive with respect to physical exercises performed in order to reduce body weight, which are applied by slightly more than a half of the students $-53.1 \%$ (Table 4).

In this respect, female students may be distinguished among whom as many as $71.3 \%$ took care of physical activity, and significantly more often appreciated the role of exercises in concern about body weight loss. Males, in concern about their silhouette, very frequently (64\%) applied physical exercises to gain body weight, and their behaviours were significantly different from those of females. Only $15.8 \%$ of female students used physical exercises in order to gain body weight.

A positive phenomenon among both male and female students was a trace use of practices which are dangerous for the organism, i.e. the taking of weight loss drugs, weight gain medicines, laxatives, diuretics, and anabolic steroids. 
The taking of weight loss drugs concerned $1.2 \%$ of males and $2.6 \%$ of females; taking diuretics $-1.4 \%$ and $2.9 \%$, respectively; laxatives $-1.2 \%$ and $2.3 \%$, and weight gain medicines $-6.5 \%$ and $0.5 \%$. The indicator concerning the use of anabolic steroids was even lower $-1.9 \%$ of males and $0.4 \%$ of females (Table 4 ). Despite trace indicators of use of dangerous agents, females significantly more frequently than males used weight loss drugs and diuretics, whereas males - weight gain medicines and anabolic steroids.

Table 4. Behaviours related with concern about own silhouette by students from Ukraine, according to sex

\begin{tabular}{|c|c|c|c|}
\hline \multicolumn{4}{|c|}{ Performance of physical exercises to lose weight } \\
\hline Sex & No & Yes & Statistics \\
\hline Females & $370(28.7 \%)$ & 921 (71.3\%) & \multirow{3}{*}{$\begin{array}{l}X^{2}=438.06 \\
p<0.0001\end{array}$} \\
\hline Males & $626(75.1 \%)$ & $208(24.9 \%)$ & \\
\hline Total & $996(46.9 \%)$ & $1,129(53.1 \%)$ & \\
\hline \multicolumn{4}{|c|}{ Performance of physical exercises to gain weight } \\
\hline Sex & No & Yes & Statistics \\
\hline Females & $1,089(84.2 \%)$ & $204(15.8 \%)$ & \multirow{3}{*}{$\begin{array}{l}X^{2}=519.88 \\
p<0.0001\end{array}$} \\
\hline Males & $300(36.0 \%)$ & $534(64.0 \%)$ & \\
\hline Total & $1,387(65.3 \%)$ & $738(34.7 \%)$ & \\
\hline \multicolumn{4}{|c|}{ Taking weight loss drugs } \\
\hline Sex & No & Yes & Statistics \\
\hline Females & $1,258(97.4 \%)$ & $33(2.6 \%)$ & \multirow{3}{*}{$\begin{array}{c}X^{2}=4.71 \\
p=0.0300^{*}\end{array}$} \\
\hline Males & $824(98.8 \%)$ & $10(1.2 \%)$ & \\
\hline Total & $2,082(98.0 \%)$ & $43(2.0 \%)$ & \\
\hline \multicolumn{4}{|c|}{ Taking weight gain drugs } \\
\hline Sex & No & Yes & Statistics \\
\hline Females & $1,285(99.5 \%)$ & $6(0.5 \%)$ & \multirow{3}{*}{$\begin{array}{l}X^{2}=66.70 \\
p<0.0001^{*}\end{array}$} \\
\hline Males & $780(93.5 \%)$ & $54(6.5 \%)$ & \\
\hline Total & $2,065(97.2 \%)$ & $60(2.8 \%)$ & \\
\hline \multicolumn{4}{|c|}{ Taking laxatives } \\
\hline Sex & No & Yes & Statistics \\
\hline Females & $1,262(97.8 \%)$ & $29(2.3 \%)$ & \multirow{3}{*}{$\begin{array}{l}X^{2}=3.08 \\
p=0.0790\end{array}$} \\
\hline Males & $824(98.8 \%)$ & $10(1.2 \%)$ & \\
\hline Total & $2,086(98.2 \%)$ & $39(1.8 \%)$ & \\
\hline \multicolumn{4}{|c|}{ Taking diuretics } \\
\hline Sex & No & Yes & Statistics \\
\hline Females & $1,254(97.1 \%)$ & $37(2.9 \%)$ & \multirow{3}{*}{$\begin{array}{r}X^{2}=4.58 \\
p=0.0323\end{array}$} \\
\hline Males & $822(98.6 \%)$ & $12(1.4 \%)$ & \\
\hline Total & $2,076(97.7 \%)$ & $49(2.3 \%)$ & \\
\hline \multicolumn{4}{|c|}{ Taking anabolic steroids } \\
\hline Sex & No & Yes & Statistics \\
\hline Females & $1,286(99.6 \%)$ & $5(0.4 \%)$ & \multirow{3}{*}{$\begin{array}{l}X^{2}=12.14 \\
p=0.0005\end{array}$} \\
\hline Males & $818(98.1 \%)$ & $16(1.9 \%)$ & \\
\hline Total & $2,104(99.0 \%)$ & $21(1.0 \%)$ & \\
\hline
\end{tabular}

Statistical significance at $p<0.05$. 


\section{Discussion}

The studies concerning the mode of nutrition of students, irrespective of the academic environment, revealed many abnormalities. One of the important issues of the equality of nutrition is the number and frequency of consumption of meals.

The Ukrainian adolescents in the study most often consumed three meals per day. Males significantly more frequently consumed four or more meals per day, and to a greater degree than females, ate two basic meals, i.e. breakfast and supper. No significant differences between sexes were found with respect to the consumption of dinner.

The number of meals consumed by the respondents was lower than that recommended by the Polish Institute of Food and Nutrition, which recommends five meals per day, but, simultaneously, indicates that this habit is observed by approximately $20 \%$ of Poles (Falkowska, 2000). The studies conducted among students of universities in Poznań (Karina, Rektor, 2005) showed that the dominant number of meals per day was three or four, which was more often reported by males, and is equivalent to the results obtained by the students from Ukraine. Different results concerning the regularity and preference of meals were obtained among students of various specialties at the Medical University in Lublin (Szponar, Krzyszycha, 2009). The dominant number of meals was from three to five per day, which was more frequently mentioned by females, who also significantly more often consumed breakfast every day. Other studies (Jasnos et al., 2003) confirmed that only $40 \%$ of female students regularly consume meals.

Female students from Ukraine do not significantly differ from their contemporaries with respect to behaviours related with nutrition. Females more often indicated the avoidance of eating, fear of gaining weight, and loss of control over eating, which may mean that their mode of nutrition is not proper. These behaviours are probably related with concern about own silhouette and wish to be attractive. It is commonly known that females, and certainly during the period of university studies, care about their silhouette. The image of female students from Ukraine is only half-way positive. More than a half of them perform exercises in order to reduce body weight. Studies among female students from the Medical University of Silesia (Jasnos et al., 2003) showed that more than a half of them applied weight loss diet at least once in their lives. In the case of males, they more often than their female colleagues applied exercises to gain weight. This was confirmed by the studies of Rasińska who found that the meals of the majority of female students were characterized by a low calorific value, which indicated a clear tendency towards slimming, also confirmed by other researchers (Jasnos et al., 2003; Wojciechów-Gazel Mickiewicz, Krzyśków, 2013). A positive phenomenon among male and female students is the trace usage of practices dangerous for the organism, such as the taking of weight loss drugs, weight gain medicines, laxatives, diuretics, and anabolic steroids. Despite the trace use of the above-mentioned agents, female students significantly more frequently consume weight loss drugs and diuretics, while males more often take medicines for gaining body weight and steroids. Studies conducted among students of the Medical University in Łódź (Łaszek, Nowacka, Gawron-Skarbek, Szatko, 2011) showed that only $0.7 \%$ of respondents regularly applied steroids. A very low percentage of males (2.8\%), and only $0.4 \%$ of females admitted that they sporadically applied steroids.

\section{Conclusions}

1. Adolescents attending universities consumed breakfast and supper nearly exclusively at home. Females significantly more often consumed breakfast at home, whereas males - second breakfast. 
2. Nearly a half of the students most frequently consumed three meals per day; nevertheless, males significantly more often ate more meals. No significant differences between sexes were found according to the consumption of dinners.

3. Significant differences were observed in the behaviours of students concerning nutrition. Females more often than males avoided eating, felt fear of gaining weight, lost control over eating, and provoked vomiting.

4. In concern about own silhouette, females significantly more often performed exercises in order to lose weight, while males in order to gain weight.

5. Trace use of medicines and other agents for improvement of the silhouette was observed. Only the taking of weight gain drugs was slightly higher, which was significantly more often noted in males.

\section{References}

Antal, M., Nagy, K, Regöly-Mérei, A., Bíró, L., Szabó, C., Rabin, B. (2006). Assessment of cardiovascular risk factors among Hungarian university students in Budapest. Ann Nutr Met, 50, 103-107. DOI: 10.1159.

Brunt, A.R., Rhee, Y.S. (2008). Obesity and lifestyle in U.S. college students related to living arrangements. Appetite, 51, 615-621.

Delinsky, S.S., Wilson, G.T. (2008). Weight gain, dietary restraint, and disordered eating in the freshman year of college. Eating Beh, 9, 82-90.

Falkowska, M. (2000). Raport COBOS - komunikat z badań: nawyki żywieniowe i upodobania kulinarne Polaków. Retrived from: www. cobos.pl (17.11.2007).

Gacek, M. (2004). Ilościowa ocena sposobu odżywiania się i preferencje żywieniowe studentów specjalizacji trenerskiej w Krakowie. Kul. Fiz., 9-10, 15-16.

Jasnos, I., Anuszewska-Mastalerz, K., Gój, K., Cieślik, A., Włodarczyk, I., Wanot, J. (2003). Styl żywienia studentek zamieszkujących w domach akademickich. Annales Universitatis Mariae-Curie Skłodowska Lublin Polonia, LVIIII, Suppl. XIII, Sectio D, 98, $531-535$.

Karina, S., Rektor, Z. (2005). Wybrane elementy stylu życia studentów kształcących się na specjalnościach związanych z medycyna. Annales Universitatis Mariae-Curie Skłodowska Lublin Polonia, LX. Suppl. XVI, Sectio D, 481, 125-129.

Kiziltan, G., Karabudak, E., Unver, S., Sezgin, E., Unal, A. (2006). Prevalence of bulimic behaviours 54321 and trends in eating attitudes among Turkish late adolescents. Adolescence, 41, 677-689.

Krzych, Ł. (2004). Analiza stylu życia studentów Śląskiej Akademii Medycznej. Zdr. Publ., 114 (1), 67-70.

Łaszek, M., Nowacka, E. Gawron-Skarbek, A., Szatko, F. (2011). Negatywne wzorce zachowań zdrowotnych studentów. Część III. Aktywność ruchowa i nawyki żywieniowe. Probl. Hig. Epidemiol., 92 (3), 461-465.

Malara, B., Góra-Kupilas, K., Jośko, J. (2006). Odżywianie się i inne elementy stylu życia studentów Politechniki Śląskiej - doniesienia wstępne. Zdr. Publ., 116 (1), 132-134.

Mammas, I., Bertsias, G., Linardakis, M., Moschandreas, J., Kafatos, A. (2006). Nutrient intake and food consumption among medical students in Greece assessed during a clinical nutrition course. Int J Food Sci Nutr, 55, 17-26.

Medrela-Kuder, E. (2003). Zainteresowanie problematyka żywienia przez studentów krakowskiej Akademii Wychowania Fizycznego. Żyw. Człow. Metab., 2 (30), 1-2.

Mięsowicz, I., Palus, D. (2002). Zachowania prozdrowotne studentów Akademii Pedagogiki Specjalnej. In: A. Malinowski (ed.), Ontogeneza i promocja zdrowia w aspekcie medycyny, antropologii i wychowania fizycznego (pp. 182-188). Zielona Góra: Wydawnictwo Uniwersytetu Zielonogórskiego.

Olędzka, R., Moczydłowska, I., Rogalska-Niedźwiedź, M. (2002). Ocena ilościowa sposobu żywienia studentów Wydziału Chemicznego Politechniki Warszawskiej w roku akademickim 1999/2000. Bromat. Chem., Toksykol., 35 (4), 310-322.

Olędzka, R., Węgłowska, K., Szczepańska-Chudy, A., Bobrowska, B. (2004). Ocena ilościowa sposobu żywienia studentów Wydziału Farmaceutycznego Akademii Medycznej w Warszawie w roku akademickim 2002/2003. XIX Naukowy Zjazd Polskiego Towarzystwa Farmaceutycznego „Farmacja - tradycja i nowoczesność". Wrocław.

Paśko, P., Krośniak, M., Chłopicka, J. Zagrodnik, I., Zachwieja, Z. (2005). Ocena sposobu żywienia studentów Wydziału Farmaceutycznego Collegium Medium Uniwersytetu Jagiellońskiego w Krakowie w latach 2003 i 2004. Część I: Składniki mineralne. Żyw. Człow. Metab., 32, 660-667. 
Popova-Ramova, E. (2015). Healthy lifestyle behaviors and nutritional habits of medical staff students. International Journal of Current Microbiology and Applied Sciences, 4 (10), 256-262.

Rasińska, R. (2009). Nawyki żywieniowe studentów w zależności od płci. Nowiny Lekarskie, 81, 354-359.

Smorczewska-Czupryńska, B., Ustymowicz-Farbiszewska, J., Cymek, P., Dubiel, J., Karczewski, J. (2009). Analiza wartości energetycznej całodziennych racji pokarmowych (CRP) studentek UM w Białymstoku oraz zawartości w nich podstawowych składników odżywczych. Bromat. Chem. Toksykol., XLII (3), 714-717.

Socha, K., Borawska, H.M., Markiewicz, R., Charkiewicz, W. (2009). Ocena sposobu odżywiania studentek Wyższej Szkoły Kosmetologii i Ochrony Zdrowia w Białymstoku. Bromat. Chem. Toksykol., XLII (3), 704-708.

Stefańska, E., Ostrowska, J., Czapska, D, Karczewski, J. (2005). Ocena poziomu spożycia wybranych składników mineralnych (Na, $\mathrm{K}, \mathrm{P}, \mathrm{Ca}, \mathrm{Mg}, \mathrm{Fe}, \mathrm{Zn}$ ) występujących w całodziennych racjach pokarmowych studentów AMB. Bromat. Chem. Toksykol., 38, 209-211.

Szponar, B., Krzyszycha, R. (2009). Ocena sposobu odżywiania studentów Uniwersytetu Medycznego w Lublinie w roku akademickim 2007-2008. Bromat. Chem. Toksykol., XLII (2), 111-116.

Wojciechów-Gazel, M., Mickiewicz, A., Krzyśków, A. (2013). Aktywność fizyczna i sposób odżywiania studentek fizjoterapii i europeistyki, a styl ich życia. Zdr. Publ., 123 (1), 19-23.

Wyka J., Żechałko-Czajkowska, A. (2007). Ocena sposobu żywienia studentów I roku Akademii Rolniczej we Wrocławiu. Roczn. PZH., $51,1,327-332$.

Zarzecka-Baran, M., Wojdak-Haasa, E. (2008). Zachowania zdrowotne studentów Akademii Medycznej w Gdańsku - sposób odżywiania. Probl. Hig. Epidemiol., 89 (1),146-150.

Cite this apticle aS: Bergier, J., Bergier, B., Tsos, A. (2016). Diversity of Nutrition among Male and Female Ukrainian Students. Central European Journal of Sport Sciences and Medicine, 16 (4), 23-31. DOI: 10.18276/cej.2016.4-03. 
